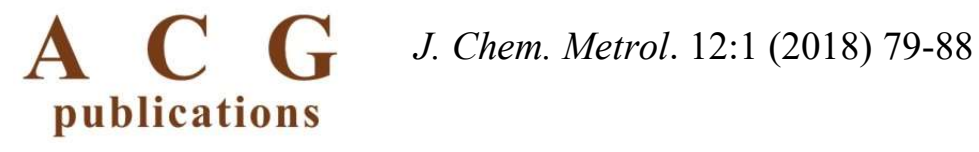

journal of chemical metrology

\title{
Comparative determination of ruscogenins content in Butcher's Broom rhizome samples gathered from the populations grown in different soil conditions in the Marmara Region and attempts for pilot field cultivation of rhizomes
}

\author{
Gulcin Ozer $\odot^{1}$, Etil Guzelmeric ${ }^{*}{ }^{2}$, Gozde Sezgin $\odot^{1}$, Ercan Ozyurek $\odot^{1}$, \\ Avni Arslan $\odot^{1}$, Ekrem Sezik $\odot^{2}$ and Erdem Yesilada $\odot^{2}$ \\ ${ }^{1}$ Marmara Forestry research Institute, Büyükdere Cad., Maslak-Sisli, 34398, Istanbul, Türkiye \\ ${ }^{2}$ Yeditepe University, Faculty of Pharmacy, Department of Pharmacognosy and Phytotherapy, Kayisdagi \\ Cad., Atasehir, 34755, Istanbul, Türkiye
}

(Received May 15,2018; Revised June 04, 2018; Accepted June 06, 2018)

\begin{abstract}
In this study, it was aimed to qualify the rhizome samples of butcher's broom (Ruscus aculeatus L.) gathered from various populations distributed naturally in The Marmara Region of Anatolia (Asian part of Turkey) based on the methods described in European Pharmacopoeia. For this purpose, rhizomes were sampled from 18 divers populations; namely, 6 from Istanbul, 4 from Bursa, 4 from Adapazarı, 2 from Balıkesir and 2 from Çanakkale. For qualitative analysis HPTLC method was used in order identify ruscogenin and stigmasterol and these were determined in all samples. For quantitative analysis, concentrations of total ruscogenin (mixture of neoruscogenin and ruscogenin) were analyzed by HPLC technique. According to The European Pharmacopoeia, Butcher's broom rhizomes should contain at least $1 \%$ ruscogenins and the rhizome samples obtained from Bahçeköy, Biga, Karacabey, Poyrazlar, Gönen and Kanlıca were found consistent with this limit. For pilot field cultivation trial, rhizome sections were prepared from the selected rhizome samples by cutting carefully from their knuckles. The sections then were planted in the nursery under 3 different crown closures with three replications (one of which to serve control). However, it was observed that the survival ratio of seedlings, which was $1 \%$ in the first year in the nursery, declined even further in the 2 nd and 3 rd years, and finally the seedlings dried up, neither developed a root system nor formed a rhizome. Consequently, further cultivation studies should be carried out under suitable climatic conditions and soil compositions by directly planting the rhizomes.
\end{abstract}

Keywords: Ruscus aculeatus L.; ruscogenin; neoruscogenin; stigmasterol; cultivation. C 2018 ACG Publications. All rights reserved.

\section{Introduction}

In Turkey, 5 taxa of Ruscus L. are registered; R. aculeatus L. var. aculeatus, R. aculeatus L. var. angustifolius Boiss., R. hypoglossum L., R. colchicus Yeo and R. hypophyllum L. [1]. Among these Ruscus aculeatus L., also called butcher's broom is a $30-60 \mathrm{~cm}$ long, often branched and evergreen shrub. It has a widespread distribution particularly along the coastal forests of Turkey. The underground parts (roots and

*Corresponding author: E-Mail: etil.ariburnu@yeditepe.edu.tr ; eyesilada@yahoo.com

The article was published by ACG Publications www.acgpubs.org/jcm (C) Published January-June 2018 EISSN:1307-6183 DOI:http://doi.org/10.25135/jcm.17.18.05.094 
rhizomes) of $R$. aculeatus are used to alleviate the symptoms of venous insufficiency, edema, premenstrual syndrome and hemorrhoids in medicinal practice $[2,3]$. Steroidal saponins (ruscogenin and neoruscogenin as aglycone and their glycosides) are determined to be the main active ingredients responsible from its pharmacological effects. The European Pharmacopoeia ( $\mathrm{Ph}$. Eur.) has set a limit to specify the qualification of rhizomes, accordingly the rhizomes should contain at least $1 \%$ of total sapogenins expressed as ruscogenins (as a mixture of neoruscogenin and ruscogenin) [4].

Its esteemed health benefits generate a high demand in pharmaceutical industry and in order to meet the increasing demand the underground parts (roots and rhizomes) are dismantled from nature in a rambling manner for about 30 years, which would drive this plant into endanger. Yearly about 2000 tons fresh or 500 tons dried roots and rhizomes are exported. The underground part of $R$. aculeatus, has been harvested mostly from three geographical regions in Turkey: Middle and Western Black Sea Regions (Samsun-Adapazar1), Aegean Region (Balıkesir, Çanakkale, Bursa, Aydın) and Mediterranean Region (Osmaniye, Adana, Antakya and K. Maraş). A study pointed out that the raw underground parts have been dismantled mostly from Adapazarı (Turkey) and France is the principal destination address [5].

In recent years, contribution of the non-wood forest products to the rural development and nature conservation have come to the forefront. If non-wood forest products can provide safe and sustainable income, it is stated that rural people will tend to prevent destruction on forests. It is also emphasized that non-wood forest products can be made sustainably without damaging the forests. But due to increased demand for such non-wood forest products and widely dismantling from nature leading to destruction of forests in many countries [6]. To prevent this genetic erosion and to provide reasonable income for forest villagers, non-wood forest products must be cultivated under suitable conditions [7].

This study primarily aimed to qualify the rhizome samples of Ruscus aculeatus which were gathered from 18 different populations distributed naturally in The Marmara Region of Turkey. For this purpose, the ruscogenin and stigmasterol contents were firstly identified qualitatively by using a high-performance thinlayer chromatographic (HPTLC) method and then their ruscogenin contents were determined by using a high-performance liquid chromatographic (HPLC) method described in the European Pharmacopoeia. In addition to analytical experiments, a pilot field trial for $R$. aculeatus rhizome production in the nursery has been carried out.

\section{Experimental}

\subsection{Chemicals and Reagents}

Acetonitrile (HPLC grade) was purchased from J. T. Baker (Deventer, the Netherlands). The other solvents were of analytical grade. Ethanol absolute, methanol, potassium hydroxide, n-butanol, dichloromethane and hydrochloric acid were purchased from Sigma-Aldrich (Steinheim, Germany).

Standards of ruscogenins (the mixture of neoruscogenin and ruscogenin), ruscogenin and stigmasterol were obtained from PhytoLab (Vestenbergsgreuth, Germany) and Sigma-Aldrich (Steinheim, Germany), respectively. Vanillin was purchased from Sigma-Aldrich (Steinheim, Germany).

\subsection{Materials}

R. aculeatus rhizomes were obtained from 18 different locations in Marmara region. The collected samples were botanically identified, the voucher specimen of materials have been kept in the Herbarium of the Yeditepe University, Faculty of Pharmacy, Department of Pharmacognosy (YEF14025-42), Turkey. The

identified samples, codes and localities of the materials are given in Table 1. Soil samples which were collected from the natural habitat of each $R$. aculeatus material as well as from the nursery were analyzed for their percentage of clay, lime, carbon, $\mathrm{pH}$ etc. contents. 
Table 1. The codes and collection sites of $R$. aculeatus samples

\begin{tabular}{|c|c|}
\hline $\begin{array}{c}\text { Location [Province] and } \\
\text { Codes }\end{array}$ & Plant Material \\
\hline
\end{tabular}

Sögütlü [Sakarya] (R1)

YEF14025

Poyrazlar [Sakarya] (R2)

YEF14026

Akyazı [Sakarya] (R3)

YEF14027

Hendek [Kocaeli] (R4)

YEF14028

Biga [Çanakkale] (R8)

Şile [İstanbul] (R10)

Bahçeköy [İstanbul] (R11)

Tekirdağ (R12)

YEF14029

Ruscus aculeatus L. var aculeatus $\quad$ YEF14030

Çatalca [İstanbul] (R13)

Mustafakemalpaşa

Ruscus aculeatus L. var angustifolius Boiss. YEF14031

YEF14032

YEF14033

(R15)[Bursa](MK Paşa)

Bandırma [Balıkesir] (R5)

YEF14035

Gönen [Balıkesir] (R6)

YEF14036

Vize [Kirklareli] (R14)

İnegöl [Bursa] (R17)

Ruscus aculeatus L. var angustifolius Boiss. YEF14037

YEF14038

Yenice [Çanakkale] (R7)

YEF14039

Kanlıca [İstanbul] (R9)

YEF14040

Yalova (R16)

Ruscus aculeatus L. var aculeatus

YEF14041

Karacabey [Bursa] (R18)

YEF14042

\subsection{Establishment of Experimental Design in the Nursery}

Firstly, rhizome sections were prepared from the selected rhizome samples by cutting carefully from their knuckles. The sections were then planted in the nursery under 3 different crown closures with three replications (one of which to serve control) according to the "Random Blocks Experimental Design". 50 rhizomes were planted in each replication of each population and thus, a total of 8100 rhizomes (50 rhizomes $\mathrm{x} 18$ populations $\mathrm{x} 3$ replications $\mathrm{x} 3$ crown closures $=8100$ ) were planted.

\subsection{Analytical Testing}

\subsubsection{Soil Analysis}

Top soil samples taken from the natural habitats of rhizome samples and the nursery were analyzed for their compositions. Soil samples were air-dried, ground and sieved with $2 \mathrm{~mm}$ screen before analysis. Particle size distribution (sand, silt and clay ratios) was determined by hydrometer method of Bouyoucos' [8] actual acidity by a $\mathrm{pH}$ meter with glass electrodes in $1 / 2.5$ distilled water, organic carbon by wet combustion method of Walkey and Black, total nitrogen $(\mathrm{N})$ by semi-micro Kjeldahl method [9].

\subsubsection{HPTLC Analysis}

\subsubsection{Preparation of Standard Solutions}

Ruscogenin and stigmasterol standard solutions $(0.05 \mathrm{mg} / \mathrm{mL})$ were prepared in methanol. 


\subsubsection{Preparation of Sample Test Solutions}

Samples prepared for HPLC analysis were also used for TLC screening.

\subsubsection{Preparation of Detection Reagent}

One gram of vanillin was dissolved in $100 \mathrm{~mL}$ sulphuric acid [10].

\subsubsection{HPTLC Method}

TLC analyses were performed according to the method described in Butcher's Broom monograph in the European Pharmacopoeia [4]. Separation was performed on the silica gel 60 F254 HPTLC glass plates $(20 \mathrm{~cm} \times 10 \mathrm{~cm})$ using the developing solvent system of dichloromethane-methanol (93:7, v/v). Sample test solutions were applied using a Linomat V automatic sample spotter (Camag, Muttenz, Switzerland). For the visual documentation, the plates were sprayed with vanillin/sulphuric acid reagent and heated in an oven at $100^{\circ} \mathrm{C}$. The derivatized plate was documented by the Camag TLC visualizer under white light. All the instruments were operated by winCATS program (version 1.4.8, Camag). The identity of the ruscogenin and stigmasterol in all samples were evaluated by comparison of the retention factors $\left(R_{\mathrm{F}}\right)$ and zone colors of ruscogenin and stigmasterol in sample and standard solutions.

\subsubsection{HPLC Analysis}

\subsubsection{Preparation of Standard Solutions}

Five $\mathrm{mg}$ of accurately weighed ruscogenins standard was dissolved in $100 \mathrm{~mL}$ of methanol.

\subsubsection{Preparation of Sample Test Solutions}

Each of powdered rhizome sample $(1 \mathrm{~g})$ was accurately weighed and placed in a $100 \mathrm{~mL}$ roundbottom flask. Then, $30 \mathrm{~mL}$ ethanol, $7.5 \mathrm{~mL}$ water and $0.1 \mathrm{~g}$ potassium hydroxide were added and heated under a reflux condenser on a water-bath for $4 \mathrm{~h}$, then cooled and filtered with a filter paper into $50 \mathrm{~mL}$ volumetric flask and diluted to $50 \mathrm{~mL}$ with ethanol. Twelve-thirty $\mathrm{mL}$ of this solution was taken and evaporated to dryness. The residue was dissolved with $5 \mathrm{~mL}$ of butanol and $1.5 \mathrm{~mL}$ hydrochloric acid and 4 $\mathrm{mL}$ of water were added. Then, the solution was heated under a reflux condenser on a water-bath for $1 \mathrm{~h}$. The solution was then diluted to $50 \mathrm{~mL}$ with methanol.

\subsubsection{HPLC Method}

HPLC analysis was performed as described in the Butcher's Broom monograph in European Pharmacopoeia [4]. HPLC analysis was carried out by Agilent Technologies 1100 series (Santa Clara, California, USA) coupled with a vacuum degasser, quaternary pump, auto-sampler, thermo-stated column compartment, and diode array detector which was operated by ChemStation 10.01 software. Separations were performed on an Agilent Zorbax Eclipse Plus C18 ODS column $(5 \mu \mathrm{m}, 250 \mathrm{~mm}$ x $4.6 \mathrm{~mm}$, i.d.). The mobile phases $\mathrm{A}$ and $\mathrm{B}$ used in this study were water and acetonitrile, respectively. The following gradient pattern was used: $60 \% \mathrm{~B}(0-25 \mathrm{~min}), 60-100 \% \mathrm{~B}$ (25-27 min), 100\% B (27-37 min). The flow rate was 1.2 $\mathrm{mL} / \mathrm{min}$, injection volume was $20 \mu \mathrm{L}$ and the detection was monitored at $203 \mathrm{~nm}$.

The percentage content of sapogenins (ruscogenins) in sample test solution was evaluated using the following equation: 


$$
\frac{A_{1} x m_{2} x 4 x p_{1}}{A_{2} x m_{1}}+\frac{A_{3} x m_{2} x 4 x p_{2}}{A_{4} x m_{1}}
$$

A1 is the area of the peak belong to ruscogenin in the sample test solution obtained with the HPLC chromatogram. A2 is the area of the peak of ruscogenin in the reference solution. A3 is the area of the peak belong to neoruscogenin in the sample test solution obtained with the HPLC chromatogram. A4 is the area of the peak of neoruscogenin in the reference solution. $\mathrm{m} 1$ is the mass of the herbal drug in the test solution. $\mathrm{m} 2$ is the mass of the ruscogenins in reference solution. $\mathrm{p}$ is the percentage content of ruscogenin and neoruscogenin. Detail of analytical method and its validation parameters can be found in Pharmacopeae Europe [4].

Table 2. Characterization of the soil samples obtained from the habitats of $R$. aculeatus samples

\begin{tabular}{|c|c|c|c|c|c|c|c|c|c|c|}
\hline $\begin{array}{c}\text { Depth } \\
\text { (cm) }\end{array}$ & $\begin{array}{c}\text { Soil } \\
\text { Sample }\end{array}$ & $\begin{array}{c}\text { Sand } \\
(\%)\end{array}$ & $\begin{array}{l}\text { Clay } \\
(\%)\end{array}$ & $\begin{array}{l}\text { Powder } \\
(\%)\end{array}$ & $\begin{array}{c}\text { Lime } \\
(\%)\end{array}$ & $\mathbf{p H}$ & $\begin{array}{c}\text { EC } \\
(\mathrm{ms} / \mathrm{cm})\end{array}$ & $\begin{array}{c}\text { Organic } \\
\text { Comp. } \\
(\%) \\
\end{array}$ & $\begin{array}{c}\mathrm{N} \\
(\%)\end{array}$ & $\begin{array}{c}C \\
(\%)\end{array}$ \\
\hline \multirow{18}{*}{$\begin{array}{l}\Xi \\
e \\
\vdots \\
o\end{array}$} & Söğ̈ütlü & 56 & 8 & 36 & 0 & 5.03 & 110 & 29.67 & 1.48 & 17.25 \\
\hline & Poyrazlar & 28 & 20 & 52 & 0 & 6.13 & 150 & 14.67 & 0.73 & 8.53 \\
\hline & Akyazı & 32 & 14 & 54 & 0 & 5.10 & 170 & 12.88 & 0.64 & 7.49 \\
\hline & Hendek & 34 & 12 & 54 & 0 & 5.20 & 90 & 19.96 & 1.00 & 11.60 \\
\hline & Bandırma & 59 & 10 & 31 & 0 & 6.55 & 90 & 10.79 & 0.54 & 6.28 \\
\hline & Gönen & 25 & 43 & 32 & 0.2 & 6.83 & 90 & 16.95 & 0.85 & 9.86 \\
\hline & Yenice & 42 & 13 & 45 & 0.2 & 6.46 & 90 & 6.68 & 0.33 & 3.88 \\
\hline & Biga & 43 & 15 & 42 & 0 & 6.49 & 160 & 31.04 & 1.55 & 18.05 \\
\hline & Kanlica & 36 & 11 & 53 & 0 & 6.58 & 120 & 27.37 & 1.37 & 15.91 \\
\hline & Şile & 66 & 11 & 23 & 0 & 5.55 & 140 & 36.73 & 1.84 & 21.35 \\
\hline & Bahçeköy & 47 & 16 & 38 & 0 & 6.00 & 140 & 19.42 & 0.97 & 11.29 \\
\hline & Tekirdağ & 21 & 18 & 61 & 0 & 7.08 & 220 & 16.56 & 0.83 & 9.63 \\
\hline & Çatalca & 86 & 6 & 8 & 0 & 6.21 & 210 & 21.07 & 1.05 & 12.25 \\
\hline & Vize & 27 & 21 & 52 & 0 & 6.72 & 130 & 32.40 & 1.62 & 18.84 \\
\hline & MKPaşa & 47 & 16 & 37 & 0 & 6.80 & 140 & 15.57 & 0.78 & 9.05 \\
\hline & Yalova & 40 & 28 & 32 & 0 & 6.42 & 280 & 12.08 & 0.60 & 7.02 \\
\hline & İnegöl & 27 & 36 & 37 & 0.76 & 7.36 & 310 & 13.77 & 0.69 & 8.01 \\
\hline & Karacabey & 36 & 7 & 57 & 0.32 & 6.79 & 250 & 18.14 & 0.91 & 10.55 \\
\hline \multirow{18}{*}{ हี } & Söğütlü & 47 & 18 & 35 & 0 & 4.19 & 120 & 6.09 & 0.30 & 3.54 \\
\hline & Poyrazlar & 28 & 24 & 48 & 0 & 6.07 & 180 & 8.52 & 0.43 & 4.95 \\
\hline & Akyazı & 23 & 22 & 55 & 0 & 5.20 & 120 & 6.92 & 0.35 & 4.03 \\
\hline & Hendek & 25 & 22 & 53 & 0 & 4.51 & 70 & 4.84 & 0.24 & 2.81 \\
\hline & Bandirma & 59 & 14 & 27 & 0 & 6.64 & 110 & 5.28 & 0.26 & 3.07 \\
\hline & Gönen & 23 & 43 & 34 & 0.4 & 6.68 & 90 & 11.97 & 0.60 & 6.96 \\
\hline & Yenice & 44 & 9 & 47 & 0 & 6.64 & 190 & 13.44 & 0.67 & 7.82 \\
\hline & Biga & 41 & 26 & 33 & 0 & 5.12 & 100 & 8.09 & 0.40 & 4.70 \\
\hline & Kanlica & 21 & 27 & 52 & 0 & 5.58 & 140 & 10.20 & 0.51 & 5.93 \\
\hline & Şile & 54 & 25 & 21 & 0 & 4.35 & 130 & 7.30 & 0.37 & 4.25 \\
\hline & Bahçeköy & 43 & 26 & 31 & 0 & 5.81 & 140 & 7.55 & 0.38 & 4.39 \\
\hline & Tekirdağ & 15 & 28 & 57 & 0 & 7.07 & 230 & 9.54 & 0.48 & 5.55 \\
\hline & Çatalca & 87 & 5 & 8 & 0 & 6.30 & 190 & 3.01 & 0.15 & 1.75 \\
\hline & Vize & 11 & 37 & 52 & 0 & 6.17 & 120 & 15.36 & 0.77 & 8.93 \\
\hline & MKPaşa & 24 & 35 & 41 & 0 & 6.27 & 150 & 31.89 & 1.59 & 18.54 \\
\hline & Yalova & 32 & 36 & 32 & 0 & 6.33 & 330 & 10.74 & 0.54 & 6.24 \\
\hline & İnegöl & 27 & 37 & 36 & 0.33 & 7.05 & 190 & 44.27 & 2.21 & 25.74 \\
\hline & Karacabey & 36 & 17 & 47 & 0.17 & 5.59 & 270 & 26.91 & 1.35 & 15.64 \\
\hline
\end{tabular}




\subsection{Statistical Analysis}

Statistical comparisons were done by using Mann-Whitney U test by using SPSS Statistics program (Version 17.0).

\section{Results and Discussion}

\subsection{Soil Analysis}

The properties of top soil samples taken from natural habitats and the nursery were given in Table 2 and 3. When the top soil samples taken from natural habitat and the nursery were compared; clay, dust and lime ratios were found to be significantly different $(p<0,01)$. It was also determined that the clay content of the nursery soil was significantly higher than that of the natural habitat.

\subsection{Planting Collected Rhizomes in the Nursery}

The collected rhizomes were planted in 3 different crown closures ( 1 control), 3 replications in the nursery according to the Random Blocks Experimental Design. It was observed that the survival ratio of seedlings, which was $1 \%$ in the first year in the nursery,

declined even further in the 2nd and 3rd years, and finally the seedlings dried up, neither developed a root system nor formed a rhizome. The compared soil samples taken from natural habitat and the top soil samples of nursery were statistically different in terms of clay, silt and lime ratios $(\mathrm{p}<0,01)$.

Table 3. Specifications of the soil samples taken from nursery

\begin{tabular}{lccccccc}
\hline Sample No & Sand (\%) & Clay (\%) & $\begin{array}{c}\text { Powder } \\
(\mathbf{\%})\end{array}$ & Lime (\%) & $\mathbf{p H}$ & EC (ms/cm) & $\begin{array}{c}\text { Organic } \\
\text { Comp. (\%) }\end{array}$ \\
\hline Soil 60 1 & 28 & 40 & 32 & 0.44 & 6.32 & 197 & 21.21 \\
Soil 60 2 & 38 & 34 & 28 & 0.24 & 6.27 & 128 & 16.29 \\
Soil 60 3 & 36 & 36 & 28 & 0.08 & 5.96 & 126 & 14.56 \\
Soil 30 1 & 30 & 42 & 28 & 0.32 & 6.39 & 157 & 15.23 \\
Soil 30 2 & 36 & 36 & 28 & 0.24 & 6.15 & 105 & 11.52 \\
Soil 30 3 & 44 & 36 & 20 & 0.24 & 6.02 & 117 & 13.98 \\
Control 1 & 28 & 40 & 32 & 0.32 & 6.42 & 184 & 17.01 \\
Control 2 & 40 & 38 & 22 & 0.32 & 6.25 & 101 & 13.64 \\
Control 3 & 40 & 36 & 24 & 0.24 & 5.91 & 103 & 15.94 \\
\hline
\end{tabular}

\subsection{HPTLC Analysis}

According to the $\mathrm{Ph}$. Eur., stigmasterol and ruscogenin are given as the reference components in $R$. aculeatus for qualitative identification by TLC. The identity of stigmasterol and ruscogenin in the test solutions of $R$. aculeatus were evaluated by comparing the $R_{\mathrm{F}}$ with the standard solutions of stigmasterol and ruscogenin $\left(R_{\mathrm{F}}=0.7\right.$ and 0.35 , respectively). The violet and yellow zone colors of the standards and sample test solutions corresponding to stigmasterol and ruscogenin, respectively, on the HPTLC plates after derivatization were compared. HPTLC analysis evidenced the existence of stigmasterol and ruscogenin in all butcher's broom samples gathered from different locations (Figure 1). 


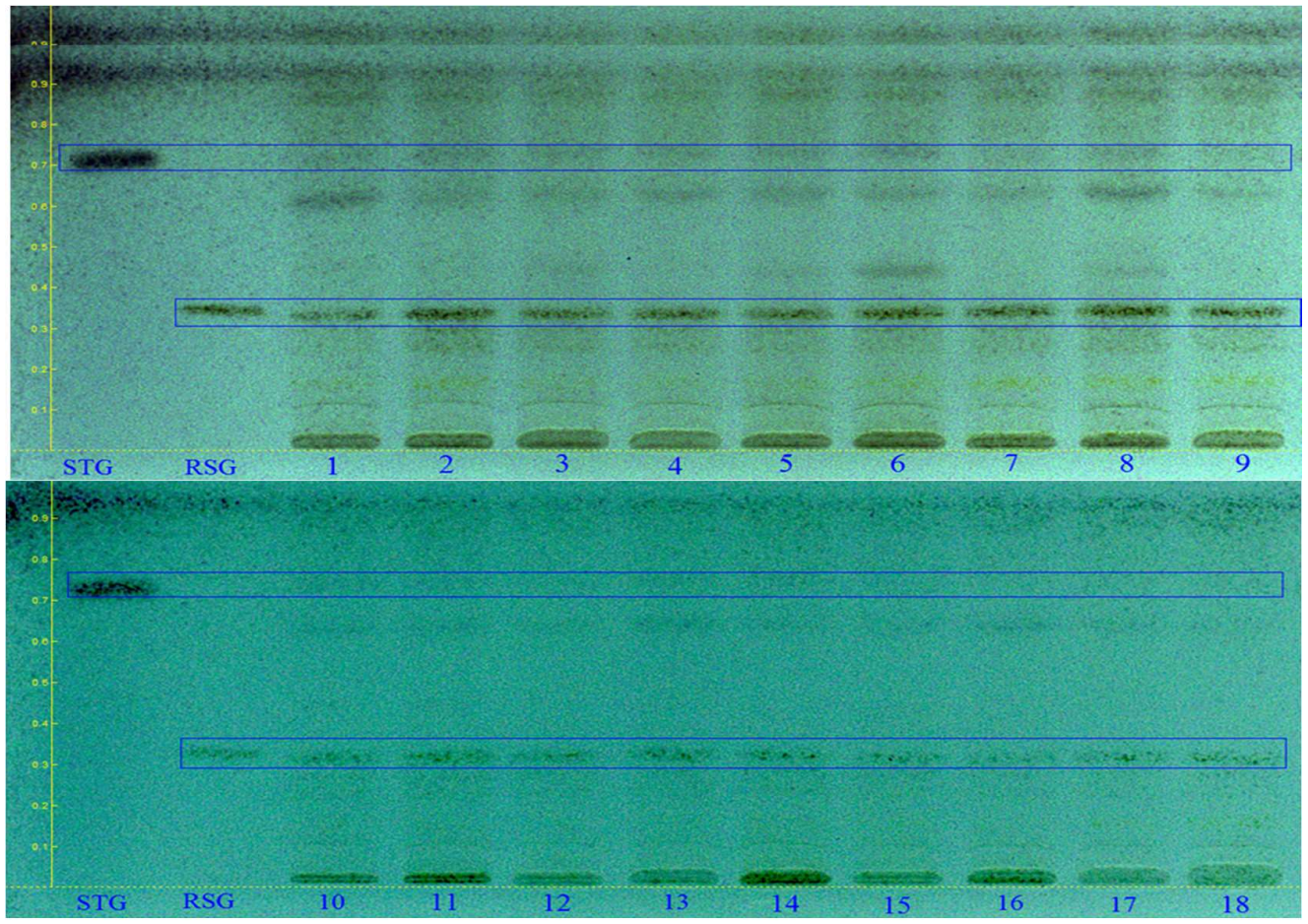

Figure 1. HPTLC chromatogram of standard and sample test solutions after derivatization under white light R1-R18: Fraction numbers, STG: Stigmasterol, RSG: Ruscogenin

\subsection{HPLC Analysis}

The relative retention time $\left(t_{\mathrm{R}}\right)$ of ruscogenin to neoruscogenin was described in the Ph. Eur. as approximately 1.2 (4). In this study, this value was determined to be $1.24 \pm 0.01(n=3)$.

A

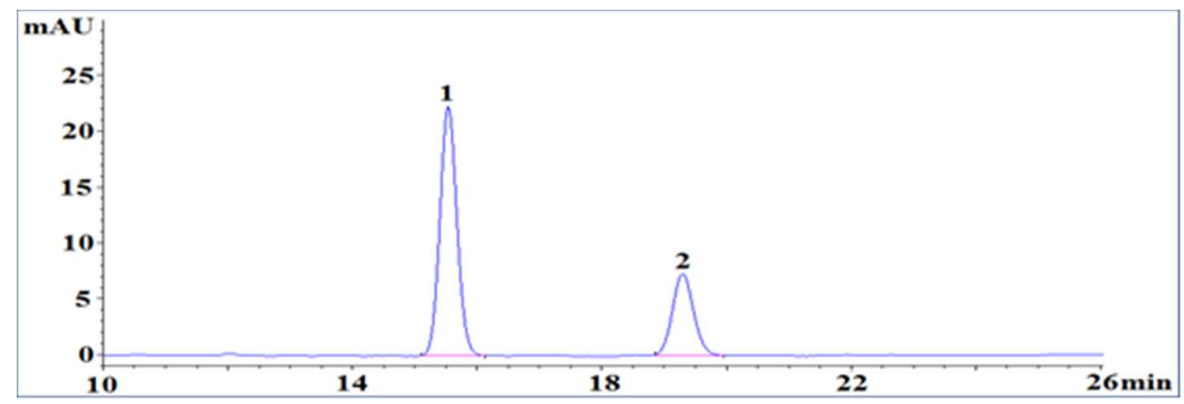

B

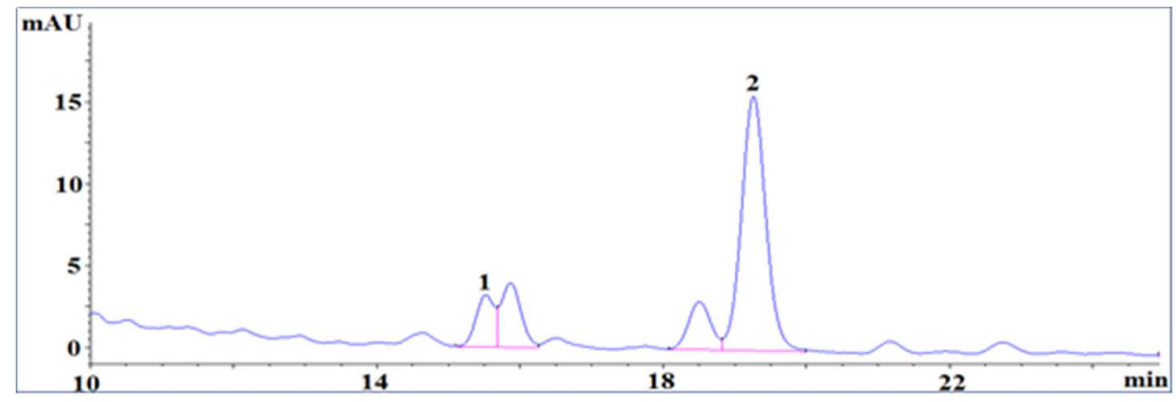

Figure 2. HPLC chromatogram of (A) standards and (B) sample test solutions at $203 \mathrm{~nm}$.

1: Neoruscogenin, 2: Ruscogenin 
The identity of the neoruscogenin and ruscogenin in test solutions were verified by comparing the $t_{\mathrm{R}}$ with the reference solution at room temperature which was found as $15.5 \pm 0.1$ and $19.3 \pm 0.1$ (min), respectively (Figure 2). Moreover, the total contents of neoruscogenin and ruscogenin expressed as ruscogenins in R2, R6, R8, R9, R11, R17 and R18 were within the limits set by the Ph. Eur. (Table 4).

Nikolov et al. [11] analyzed the ruscogenin content in above-ground and underground parts of $R$. aculeatus and $R$. hypoglossum by using a TLC-densitometric method. Accordingly, they determined the amount of ruscogenin in the underground and the above-ground parts of $R$. hypoglossum as 0.14 and $0.10 \%$, respectively, while for $R$. aculeatus these concentrations were 0.12 and $0.08 \%$. Vlase et al. [12] quantified both ruscogenin and neoruscogenin concentrations in different plant parts of $R$. aculeatus by using HPLCmass spectrometry and they found that the highest sapogenin content was found in the rhizomes. The results were as follows (ruscogenin vs. neoruscogenin): $0.020 / 0.046 \%$ in the roots; $0.111 / 0.173 \%$ in the rhizomes; and $0.112 / 0.027 \%$ in the phylloclades. These values were far below the least ruscogenin content determined in the present study as $0.505 \%$ in R16 sample which was collected from Yalova.

Table 4. Total Ruscogenin content in the R. aculeatus samples

\begin{tabular}{cc}
\hline Samples & Ruscogenin Content $(\%)(\mathbf{n}=\mathbf{3})$ \\
\hline R1 & $0.539 \pm 0.008$ \\
R2 & $1.128 \pm 0.069$ \\
R3 & $0.812 \pm 0.055$ \\
R4 & $0.914 \pm 0.049$ \\
R5 & $0.833 \pm 0.009$ \\
R6 & $1.068 \pm 0.053$ \\
R7 & $0.824 \pm 0.035$ \\
R8 & $1.420 \pm 0.012$ \\
R9 & $1.021 \pm 0.029$ \\
R10 & $0.802 \pm 0.009$ \\
R11 & $1.497 \pm 0.036$ \\
R12 & $0.800 \pm 0.071$ \\
R13 & $0.769 \pm 0.015$ \\
R14 & $0.712 \pm 0.029$ \\
R15 & $0.683 \pm 0.063$ \\
R16 & $0.506 \pm 0.063$ \\
R17 & $0.983 \pm 0.089$ \\
R18 & $1.228 \pm 0.186$ \\
\hline
\end{tabular}

There are also several other studies previously reporting the ruscogenins contents in Turkish Ruscus taxa samples. Tansi et al. [13] investigated the ruscogenin content in the underground and aerial parts of $R$. aculeatus samples collected from different localities in Southern Turkey by HPLC method. Accordingly, the ruscogenin concentrations in the underground and the aerial parts were found to be between 0.02-0.12 and 0.03-0.05\%, respectively. The authors also pointed out that ruscogenins content (ruscogenin together with neoruscogenin) in the underground parts of $R$. aculeatus were higher than the aerial parts. The highest value of ruscogenins was found as $0.12 \%$ in the sample obtained from İncebel (Osmaniye, Turkey). However, the calculated value was not met the criteria as stated in Ph. Eur. In another study, Güvenç et al. (14) determined the ruscogenin contents in the aerial and underground parts of five Ruscus taxa (R. aculeatus var. aculeatus, $R$. aculeatus var. angustifolius, $R$. colchicus, $R$. hypoglossum and $R$. hypophyllum) from the coastal Northern and Southern regions of Turkey by using TLC and ultra-performance liquid chromatographic (UPLC) methods. According to the TLC chromatogram after derivatization with $20 \%$ antimony chloride in chloroform, ruscogenin was detected as a purple zone in all investigated samples. UPLC analysis experiments have revealed that the total ruscogenin content which was determined after acid hydrolysis in each Ruscus species showed variations from species to species as well as to the collection site of the sample. If the limits set by Eur.Ph. for ruscogenins content (over 1.0\%) take into consideration, the highest concentrations were found in the rhizomes of $R$. hypoglossum [1.42\%] (Tirebolu, Giresun), $R$. colchicus [1.40\%] (Ordu, Ünye) and $R$. hypophyllum [1.08\%], while in the aerial parts of $R$. aculeatus var. aculeatus [1.48\%] (Karasu, 
Sakarya) and $R$. aculeatus var. angustifolia [1.36\%]. This later value seems conflicting with the previously published data that ruscogenin content in the rhizomes of $R$. aculeatus was higher than in the aerial parts. On the other hand, ruscogenins concentrations of the other samples was found to be far below the official value.

\section{Conclusions}

In the present study, stigmasterol and ruscogenin were identified in all samples collected from different localities in The Marmara Region. Furthermore, sapogenins contents expressed as ruscogenins (mixture of neoruscogenin and ruscogenin) were quantified in these samples. The total content of ruscogenins in R2, R6, R8, R9, R11, R17 and R18 were found to be over 1\%. Results of the both qualitative (HPTLC) and quantitative (HPLC) analysis of these samples met the reference criteria set by Ph. Eur. On the other hand, not any significant correlation has been put forth between the active ingredient content and the soil properties of the habitats. However, the samples possessing higher active ingredients were collected from the localities where dismantling was not done. Accordingly, the higher age of the rhizomes of R2, R6, R8, R9, R11, R17 and R18 may be an explanation for the higher content of active ingredient. On the other hand, the field cultivation trials of collected rhizomes in the nurseries were not achieved successfully at the end of 3years of trial period. For further studies, it may be proposed that $R$. aculeatus cultivation studies should be practiced under different soil properties, suitable climatic conditions and by planting the whole rhizomes instead of rhizome slices.

\section{Acknowledgements}

This project is funded by Republic of Turkey Ministry of Forestry and Water Affairs (Project no: 10.7702).

\section{ORCID}

Gülçin Özer: 0000-0001-8791-3715

Etil Güzelmeric: 0000-0001-9696-3271

Gözde Sezgin: 0000-0002-8285-6237

Ercan Özyürek: 0000-0001-9806-8457

Avni Arslan: 0000-0001-8486-9667

Ekrem Sezik 0000-0002-8284-0948

Erdem Yesilada: 0000-0002-1348-6033

\section{References}

[1] P.H. Davis (1984). Flora of Turkey and The East Aegean Islands, University Press, Edinburgh.

[2] M. Masullo, C. Pizza and S. Piacente (2016). Ruscus Genus: A rich source of bioactive steroidal saponins, Planta Med. 82, 1513-1524.

[3] European Scientific Cooperative on Phytotherapy (E/S/C/O/P) (2003). Second ed., Thieme.

[4] European Pharmacopoeia (Ph. Eur.)(2010), Seventh ed., Council of Europe, Strasbourg.

[5] M. Coşkun, A. Güvenç, C.S. Erdurak and O. Arıhan (2003). Ticareti yapılan Ruscus türlerinin Türkiye'deki durumunun incelenmesi, TÜBİTAK TBAG-2065 (101T076) Project Final Report.

[6] Orman Genel Müdürlüğ̈̈, (2012). Kuruluşunun 60. yılında ormancıllk araştırma enstitüleri: Dünü, Bu günü ve Geleceği Sempozyumu,Bildiriler Kitabı.

[7] O. Arabacı, E. Bayram, H. Baydar, F. Savran, T. Karadoğan and N. Özay (2003). Bazı aromatik bitkilerin Aydın, Isparta ve Çanakkale ekolojik koşullarına adaptasyonu ve agronomik-teknolojik önceliklerinin belirlenmesi üzerine çalışmalar. TARP Project No:2447.

[8] G.J. Bouyoucos (1962). Hydrometer method improved for making particle size analysis of soils, Agron. J. 54, 64-65.

[9] M.Ö. Karaöz MÖ (1989). Toprakların bazı kimyasal özelliklerinin (pH, karbonat, tuzluluk, organic madde, total azot, yararlanılabilir fosfor) analizi yöntemleri, J. Fac. For. İstanbul U. 39, 64-82.

[10] E. Reich and A. Schibli (2007). High performance Thin Layer Chromatography for the analysis of medicinal plants, Thieme. 
[11] S. Nikolov, M. Joneidi and D. Panova (1976). Quantitative determination of ruscogenin in Ruscus species by densitometric thin-layer chromatography, Pharmazie 31, 611-612.

[12] L. Vlase, B. Kiss, G. Balica, M. Tămas, G. Crisan and S.E. Leucuta (2009). High-throughput LC/MS/MS analysis of ruscogenin and neoruscogenin in Ruscus aculeatus L., J. AOAC Int. 92, 1055-1059.

[13] S. Tansi, G. Kökdil, S. Karaman, O. Toncer and H. Yilmaz (2007). Variation in ruscogenin contents in Ruscus aculeatus L. growing wild in southern Turkey, Asian J. Chem. 17, 3015-3022.

[14] A. Güvenç, E. Şatır and M. Coşkun (2007). Determination of ruscogenin in Turkish Ruscus L. species by UPLC, Chromatographia 66, S141-S145.

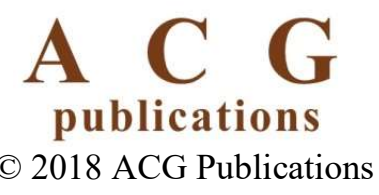

